\title{
NEVADA BIRD RECORDS COMMITTEE REPORT FOR 2017
}

JEANNE TINSMAN, 5025 Wildroot Rd., Las Vegas, Nevada, 89130;

philohela17@gmail.com

MARTIN MEYERS, c/o Great Basin Bird Observatory, 1755 E. Plumb Lane \#256, Reno, Nevada 89502; NevadaBirdRecords@gbbo.org

ABSTRACT: In 2017, the Nevada Bird Records Committee reviewed 83 reports from the period 6 February 1940-1 November 2017; 66 were endorsed. Two new species, the White Ibis (Eudocimus albus) and the Arctic Warbler (Phylloscopus borealis) sensu lato, were added to the Nevada list following endorsement of the first state records. The endorsement of a record of the Black Rail (Laterallus jamaicensis) completed our years-long project to have endorsed records for every species on the Nevada list that the committee reviews. The Nevada state list now stands at 489 species, while the review list contains 141 species and two subspecies.

The Nevada Bird Records Committee (NBRC) began 2017 with 21 reports pending review. During 2017, we added 83 reports to the pending queue. The committee completed reviews of 83 reports during the year. One record was removed from the queue when it was combined with another as representing a "continuing" bird, and one record was withdrawn by the submitter before circulation. Thus the year ended with 19 in the pending queue. Since its founding in 1994, the NBRC has reviewed 1345 reports, endorsing 1213 (90.2\%) of them.

At its founding in 1994, the committee decided not to review any sightings prior to that year, but it reversed that decision several years later. Fortunately, founding secretary James Cressman and his wife, Marian, continued to accumulate documentation for "pre-committee" reports. One of the committee's long-term goals since 2007 has been to organize and review as many of those reports as possible. In addition, the NBRC has also searched for additional reviewable documentation from multiple sources (e.g., museum specimens and journal articles) for early unreviewed reports. Since 2007, the committee has reviewed 233 reports of sightings prior to the year 2000. Of those, 197 have been endorsed. Of the 83 reports reviewed in 2017, 33 preceded the year 2000, and 27 of them were endorsed. Fourteen of those were the earliest NBRC-endorsed records for Nevada. 
Of the 83 reports reviewed by the committee in 2017, 66 were endorsed. Photographs accompanied the documentation for 53 of the endorsed records. Of those 53, two were also accompanied by a video recording, another by an audio recording. Three were supported by video recordings alone (two to capture sound, with the bird not visible). Fourteen were supported by museum specimens. Of the 17 reports that were not endorsed, only three were supported by photographs; the rest were supported only by written descriptions, and none was supported by a video recording, audio recording, or specimen.

The NBRC has six voting members, one of whom serves as chair, and a nonvoting secretary. During 2017, the committee's voting members were Aaron Ambos, Paul Hurtado, Greg Scyphers, Justin Streit, Jeanne Tinsman, and Ben Zyla. The position of secretary continued to be held by Martin Meyers, and the postion of chairperson continued to be held by Jeanne Tinsman.

The NBRC's website at http:/gbbo.org/nbrc contains a statement of purpose, answers to frequently asked questions, links to a submission form that can be downloaded or completed online, the Nevada checklist, the review list, a list of current and past members, and the committee's bylaws. There is a link to a list of all submissions to the NBRC, with the status of each with respect to endorsement and, if available, a photograph. All previous NBRC reports are available through the website. NBRC reports through 2007 (1994-1996, 1997, 1998, 1999, 2000, 2004, 2005, and 2007) appeared in Great Basin Birds, published by the Great Basin Bird Observatory. Reports for 2008 through 2010 are available only at the NBRC website. Beginning with the 2011 report, annual reports have appeared in Western Birds.

\section{REVISIONS TO THE NEVADA STATE LIST}

In 2017, two species were added to the Nevada list, and one species was removed. The White Ibis (Eudocimus albus) and the Arctic Warbler (Phylloscopus borealis) sensu lato were added following endorsement of first state records. The Thayer's Gull (Larus thayeri) was removed from the Nevada list following its merger in the Iceland Gull as Larus glaucoides thayeri (Chesser et al. 2017). The Iceland Gull was already on the Nevada list on the basis of a single record, in 2011, of subspecies kumlieni.

Early in its history, the NBRC adopted an existing checklist (Titus 1996) based on numerous sources that constituted the most reliable information available at the time. By the end of 2016, the committee had nearly completed an extensive search for reviewable documentation for all of the rare species on that list (those constituting the review list; Tinsman and Meyers 2016). The only remaining rare species on the list without an endorsed record at the end of 2016 was the Black Rail (Laterallus jamaicensis), of which the committee had in its database two reports not endorsed. In 2017, two reports were received and reviewed; one was supported by an audio file and endorsed, and the other contained written documentation only and was not endorsed. See below for details.

At the end of 2017, the Nevada state list stood at 489 species. 


\section{REVISIONS TO THE NEVADA REVIEW LIST}

Added to the Nevada review list in 2017 were the new additions to the Nevada checklist, the White Ibis and the Arctic Warbler (Phylloscopus borealis) sensu lato. Removed from the review list, on the basis of the taxonomic change described above, were the Thayer's Gull and the Iceland Gull; L. glaucoides thayeri is a regular visitor to the state.

There are currently 141 species on the Nevada review list, of which seven are exempt from review in some limited geographic area. In addition, two subspecies are currently on the review list: the Mexican Mallard (Anas platyrhynchos diazi) and Eurasian Green-winged Teal (Anas crecca crecca). The committee has endorsed four records of the Eurasian Green-winged Teal. The committee placed Mexican Mallard on the review list to accumulate data on its occurrence. We have five unreviewed reports of this subspecies but have decided to wait to review them until there is more clarity on this subspecies' taxonomic status and identification criteria.

\section{SPECIES ACCOUNTS}

Each species account is introduced with a header in the following format: English name; scientific name; and, in parentheses, the total number of endorsed records of the species (including those endorsed in this report), followed by the number of records endorsed in this year's report. An asterisk preceding the species' name signifies that the species is no longer on the Nevada review list. Two asterisks after the total of records denote that the number of records refers to a restricted review period, usually signifying that the species is no longer on the review list, was added to the review list because of a perceived drop in population, or is exempt from review in some locations.

After the heading for each species, each report of that species reviewed in 2017 is provided in the following format: NBRC report number, location (county in parentheses), and date or range of dates of observations submitted to the NBRC. If the report involved multiple birds, the number follows the date information. Then, for endorsed records, the name of each submitter, followed by the notation "(P)," "(V)," and/or "(A)" if he or she provided a photo, video, and/or audio recording, respectively; if there is no such annotation, only written documentation was provided. If the finder(s) sent documentation to the NBRC, their names are listed first. A semicolon follows the finders' names if other observers submitted additional documentation.

In cases where a specimen was the subject of review, the collector is identified, followed by the museum accession number along with sex, age, and condition as available. The museums cited in this report are the Marjorie Barrick Museum (MBM; formerly at the University of Nevada, Las Vegas; the collection is now housed at the University of Washington Burke Museum, Seattle [UWBM]); the Nevada State Museum in Carson City (NSM); and the University of Nevada, Reno, Museum of Natural History (UNMB), formerly the University of Nevada Museum of Biology. In all instances, the committee examined photographs of the specimens, and the photographs are included in the documentation. 
Multiple observations of a species are ordered chronologically. Any discussion of the species in general, not specific to an observation, concludes the account if warranted.

BRANT Branta bernicla (8, 1). 2017-020, Ash Meadows National Wildlife Refuge (NWR) (Nye), 7 Apr 1996. M. Cressman (P, Natl. Audubon Soc. Field Notes 50:308, 1996). Adult, subspecies nigricans.

TRUMPETER SWAN Cygnus buccinator $\left(4^{* *}, 1\right)$. 2017-003, Pahranagat NWR (Lincoln), 16 Jan 2017, two birds. P. Gaffey, C. Gaffey (P; Figure 1).

2017-012, Caliente (Lincoln), 19-21 Feb 2017. NOT ENDORSED. This juvenile bird showed features suggesting the Trumpeter Swan, notably, a "V" shape to the forehead feathering and a culmen straighter than in a typical Tundra Swan $(C$. columbianus). The bill showed no yellow at the base, but it did have a white patch in that location. Also, the eyes looked isolated from the bare parts of the lores and bill. Bruce Deuel, California Department of Fish and Wildlife biologist, stated, "none of the i.d. characters are definitive by themselves, especially in juveniles" (in litt., 2017). He pointed out that some Trumpeter-like anomalies of the bill should not be considered definitive in a juvenile. Also, the lack of any dark plumage on the body in February is a stronger indicator of the Tundra Swan than any of the features that pointed toward the Trumpeter.

BLACK SCOTER Melanitta americana (13, 1). 2016-060, Warrior Point, Pyramid Lake (Washoe), 11-12 Dec 2016. G. Scyphers (P); F. Petersen (P; see this issue's front cover). Adult female. Nevada has had at least one record of the Black Scoter in six of the last 10 years.

COMMON GROUND-DOVE Columbina passerina (7, 2). 2017-052, Corn Creek, Desert NWR (Clark), 9 Jun 1967. Collected by C. G. Hansen (MBM 1310 [B-965]/UWBM 97458; , skull ossified, light fat). Earliest NBRC-endorsed record, though Austin (1968a) stated it was the fourth for Nevada.

2017-058, Carson City (Carson City), 1 Jul 1969. Collected by B. Arkell (NSM 177 ; ㅇ)

2017-042, Virgin River floodplain east of Logandale (Clark), 16 Jun 2017. NOT ENDORSED.

The NBRC has now endorsed three records of this species prior to 1973. Alcorn (1988:183) considered the Common Ground-Dove to be of "irregular occurrence in southern Nevada." In spite of additional reports he listed for 1976 and 1982, we have no well-documented reports from 1973 through 2009 . We received documentation for six individuals reported between 2009, and the end of 2017, five had been endorsed by the committee and one was still pending review.

RUDDY GROUND-DOVE Columbina talpacoti (8, 5). 2017-069, Amargosa Valley (Nye), 25 Sep 1990. G. H. Rosenberg (P), P. E. Lehman (Am. Birds 45:133, 1991). Earliest NBRC-endorsed record.

2017-033, Indian Springs (Clark), 24 Oct 1991. M. Cressman (Am Birds 46:128, 1992).

2017-032, Amargosa Valley (Nye), 21 Oct 1992. S. Finnegan (P); P. E. Lehman (Am. Birds 47:125, 1993).

2017-070, Indian Springs (Clark), 23-25 Sep 1995, three birds. S. B. Terrill (P), M. A. Patten (Natl. Audubon Soc. Field Notes 50:87, 1996).

2017-038, Lake Las Vegas (Clark), 15 Jan 2017. J. Aufmann (P; Figure 2).

Five of Nevada's eight records are of birds observed between September 1990 and November 1995. The next record came nearly 10 years later in October 2005, another nine years passed before the species was observed again (2014). 


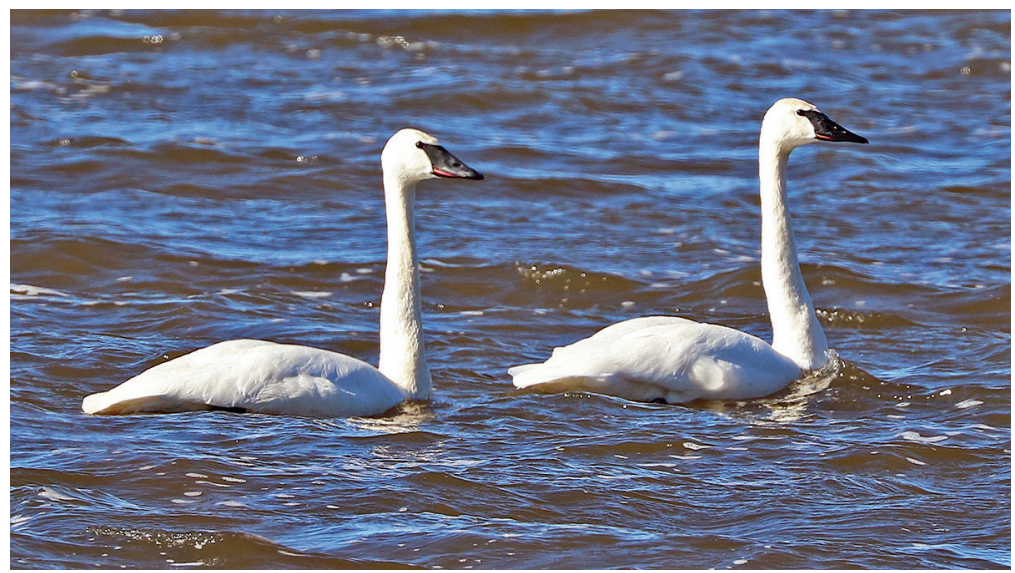

Figure 1. Trumpeter Swans (Cygnus buccinator), 16 Jan 2017, Pahranagat National Wildlife Refuge, Lincoln County, Nevada.

Photo by C. Gaffey

CHIMNEY SWIFT Chaetura pelagica (0, 0). 2017-029, Dyer (Esmeralda), 26 May 1991. NOT ENDORSED.

BROAD-BILLED HUMMINGBIRD Cynanthus latirostris (8, 1). 2017-001, Mesquite (Clark), 4-18 Jan 2017. N. Batchelder (P; Figure 3); D. Boyarski (P). Banded by Batchelder.

BLACK RAIL Laterallus jamaicensis (1, 1). 2017-007, Duck Creek, Clark County Wetlands Park (Clark), 24 Sep 2009. NOT ENDORSED.

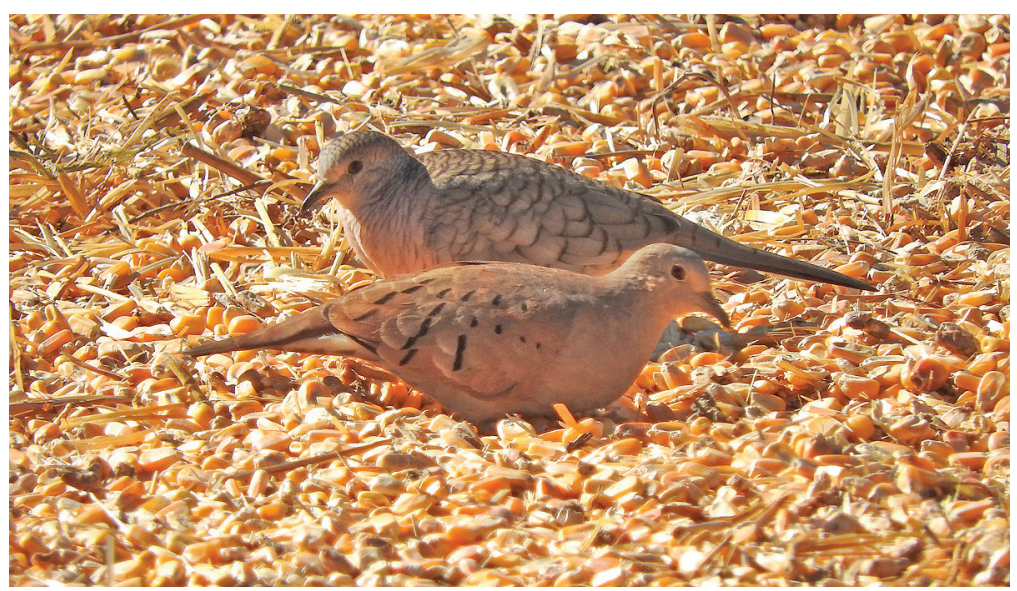

Figure 2. Ruddy Ground Dove (Columbina talpacoti) with Inca Dove (Columbina inca), 15 Jan 2017, Lake Las Vegas, Clark County, Nevada.

Photo by J. Aufmann 


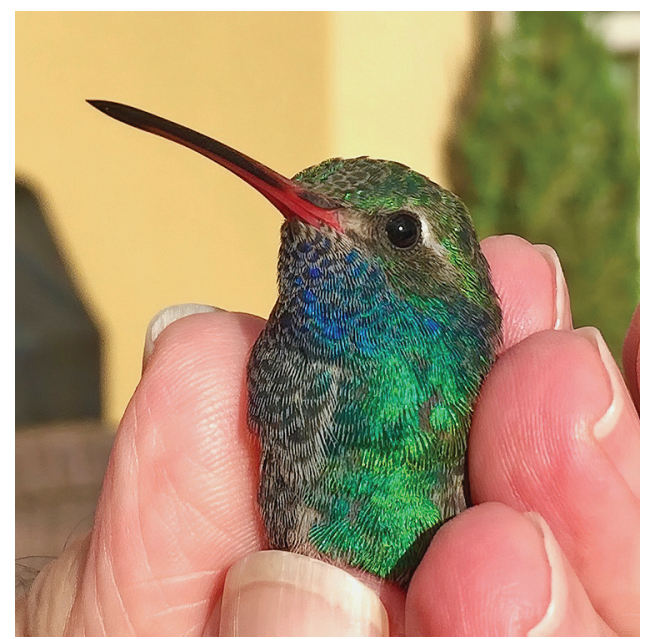

Figure 3. Broad-billed Hummingbird (Cynanthus latirostris), 4-18 Jan 2017, Mesquite, Clark County, Nevada.

Photo by N. Batchelder

2017-010, Virgin River floodplain east of Logandale (Clark), 8-16 Jun 2016. C. Klinger (V). First endorsed record for Nevada. While surveying for the Southwestern Willow Flycatcher (Empidonax traillii extimus) on 8 and 16 Jun 2016, Christy Klinger heard a Black Rail, loudly vocalizing its distinctive "kik-kee-doo." Though the rail was not visible, she submitted a cell-phone video with accompanying audio, along with written details. The endorsement of this record by the committee completed the years-long effort to have at least one endorsed record for every rare species on the Nevada checklist.

PURPLE GALLINULE, Porphyrio martinica (3, 2). 2017-057, Eureka (Eureka), 25 Nov 1965. Collected by A. Biale (MBM [B-1661]/UWBM 98430; Alcorn 1988). Earliest NBRC-endorsed record.

2017-056, Floyd Lamb Park (Clark), 8 Sep 1966. Collected by G. T. Austin (MBM 483 [B-668]/UWBM 98429; o", no fat). Austin (1968b) reported seeing it the previous day and another individual on 20 Sep, 12 days after collecting the specimen.

There have been no Nevada records since 1995.

AMERICAN GOLDEN-PLOVER Pluvialis dominica (9, 1). 2017-036, Mason Valley Wildlife Management Area (WMA) (Lyon), 8-9 May 2017. F. Welden (P), M. Andrews.

PACIFIC GOLDEN-PLOVER Pluvialis fulva (2, 1). 2017-031, Carson Lake (Churchill), 11 Aug 1988. P. E. Lehman. Earliest NBRC-endorsed record. Lehman's documentation specified features of fulva, though at the time the AOU checklist ranked it as a subspecies of $P$. dominica.

MOUNTAIN PLOVER Charadrius montanus (11, 2). 2016-055, Crystal Springs (Lincoln), 14 Oct 2016. J. F. Holmes (P).

2017-005, Washoe Lake State Park (SP) (Washoe), 31 Oct 2016. G. Scyphers (P).

Seven of Nevada's 11 endorsed records for this species, accounting for 28 of the 
34 individuals reported, are from October. Of the remaining four records, one is from January and three are from August.

PARASITIC JAEGER Stercorarius parasiticus $(16,5)$. 2017-017, The Willows, Pyramid Lake (Washoe), 3 Sep 2016. N. Rosen (P).

2016-047, Henderson Bird Viewing Preserve (Clark), 4 Sep 2016. A. Harper, B. Miller (P).

2016-045, Washoe Lake (Washoe), 6 Sep 2016. J. Bleam (P).

2016-053, south end of Pyramid Lake (Washoe), 24 Sep 2016. C. Coxe (P),

K. Drozd (P).

2016-059, south end of Pyramid Lake (Washoe), 29 Oct-6 Nov 2016. D. Ghiglieri

(P), R. Strickland; C. Dodson, M. Meyers (P), G. Scyphers (P; Figure 4), P. Hurtado

(V), J. Bleam (P), F. Petersen (P), C. Coxe (P).

2017-048, Las Vegas Bay, Lake Mead National Recreation Area (NRA) (Clark), 4 Sep 2017. NOT ENDORSED.

Of the 16 Nevada records of the Parasitic Jaeger, two are from August, 12 from September, and two from October.

LONG-TAILED JAEGER Stercorarius longicaudus (13, 1). 2017-018, The Willows, Pyramid Lake (Washoe), 3 Sep 2016. N. Rosen (P); F. Welden (P).

BLACK-LEGGED KITTIWAKE Rissa tridactyla (10, 2). 2017-019, Las Vegas Bay, Lake Mead NRA (Clark), 28 Nov 1987-19 Feb 1988. J. Kaplan (P, Am. Birds 42:301, 1988).

2016-056, Las Vegas Bay, Lake Mead NRA (Clark), 23-24 Oct 2016. B. Miller (P), A. Harper, B. Zyla.

LAUGHING GULL Leucophaeus atricilla (3, 1). 2017-045, Boulder Beach, Lake Mead NRA (Clark), 8 Jul 1995. M. Cressman (P; Natl. Audubon Soc. Field Notes 49:956, 1995). Nevada has had no records of the Laughing Gull since 2004.

WESTERN GULL Larus occidentalis (8, 0). 2017-015, Ash Meadows NWR (Nye), 9 Mar 2017. NOT ENDORSED.

YELLOW-BILLED LOON Gavia adamsii (9, 0). 2017-008, Ash Meadows NWR (Nye), 16 Dec 2016. NOT ENDORSED.

LITTLE BLUE HERON Egretta caerulea (5, 1). 2017-044, Pahranagat NWR (Lincoln), 7 Aug 2017. J. Taylor (P). Adult.

WHITE IBIS Eudocimus albus (1, 1). 2017-046, Clark County Wetlands Park and Henderson Bird Viewing Preserve (Clark), 13-21 Aug 2017. K. McGoohan; D. Crowe (P), P. Gaffey, C. Gaffey (P), J. Tinsman (P; Figure 5), G. S. Clemson (P). First endorsed record for Nevada. Adult. Originally observed along the Las Vegas Wash in the Clark County Wetlands Park, it made its way back and forth from that location to the nearby Henderson Bird Viewing Preserve over several days.

Utah has three records of the White Ibis. One of these was of an adult around the Great Salt Lake (7 Jun-27 Jul 2017) just prior to the discovery of the adult in southern Nevada (http://www.utahbirds.org/RecCom/RareBirdsIndex.html).

COMMON BLACK HAWK Buteogallus anthracinus (13**, 0). 2017-034, Pahrump (Nye), 21 Apr 2017. NOT ENDORSED. This species is exempt from review in the Meadow Valley Wash/Rainbow Canyon area, which accounts for seven of $\mathrm{Ne}$ vada's 13 records (12 individuals) and where it has nested successfully (Meyers 2016).

HARRIS'S HAWK Parabuteo unicinctus (12, 4). 2017-051, Henderson (Clark), 1 Jul 1996. Road kill salvaged by the U.S. Fish and Wildlife Service (MBM 5269/ UWBM 98130; ㅇ). Earliest NBRC-endorsed record.

2016-046, Summerlin, Las Vegas (Clark), 30 Aug-9 Sep 2016. N. McDonal; J. Thompson, N. Santos. 
2017-014, Floyd Lamb Park (Clark), 21 Mar-2 Apr 2017, two birds. B. Morrison (P), P. Gaffey (P; Figure 6), J. Tinsman (P). A photo taken 2 Apr 2017 shows the pair copulating. Reports of this species continued on the NVBirds listserv, www.eBird. org, and Facebook until at least mid-April, and one post related that a single bird was observed into May. One of the birds was reportedly found injured in mid-April, and it did not survive. The specimen was not preserved.

2017-023, Searchlight (Clark), 10 Apr 2017. L. Harter, J. Tobin.

"BROAD-WINGED HAWK Buteo platypterus (8**, 0). 2016-038, Corn Creek, Desert NWR (Clark), 12 Apr 1992. NOT ENDORSED.

2016-039, Overton WMA (Clark), 17 Apr 1993. NOT ENDORSED.

TROPICAL KINGBIRD Tyrannus melancholicus (1, 0). 2017-009, Las Vegas (Clark), 5 Jul 2014. NOT ENDORSED.

SCISSOR-TAILED FLYCATCHER Tyrannus forficatus (12, 3). 2017-050, Diamond Valley (Eureka), 21 May 1965. Collected by A. Biale (MBM 1709 [B-1724]/ UWBM 98858; $\left.0^{\top}\right)$. Earliest NBRC-endorsed record.

2017-011, Bunkerville (Clark), 30 Jun 2016. C. Klinger (P), C. Tomlinson (P).

2017-064, Wendover (Elko), 5 Jun 2017. K. Kough (V).

WHITE-EYED VIREO Vireo griseus (8, 1). 2017-039, Ash Meadows NWR (Nye), 11 May 2017. D. Crowe (V).

HUTTON'S VIREO Vireo huttoni (0, 0). 2017-013, Spring Mountain Ranch SP (Clark), 28 Feb 2017. NOT ENDORSED. Though Alcorn (1988) mentioned a few observations and specimens collected in Nevada, the NBRC has uncovered no written documentation, photographs, or specimens despite an exhaustive search. Without such evidence, this species was removed from the Nevada checklist in September 2015. In the case of the report in 2017, the observer was sure of his identification but was unable to provide the level of documentation appropriate to reinstating Hutton's Vireo on the checklist as a first state record.

YELLOW-THROATED VIREO Vireo flavifrons (8, 1). 2017-037, Floyd Lamb Park (Clark), 9 May 2017. G. Scyphers (P, A).

PHILADELPHIA VIREO Vireo philadelphicus (5, 2). 2016-061, Spring Mountain Ranch SP (Clark), 23 Oct 2016. A. Jaramillo (P).

2017-049, Ruby Mountains (Elko), 6 Sep 2017. C. Chappell.

PURPLE MARTIN Progne subis (16, 2). 2016-051, Duck Creek, Clark County Wetlands Park (Clark), 1 Aug 2016. B. Zyla.

2017-016, Palm Gardens (Clark), 12 Mar 2017, four birds. C. Van Oosten.

2017-035, Currant Ranch (White Pine), 14 Apr 2017. NOT ENDORSED.

ARCTIC WARBLER Phylloscopus borealis (sensu lato) (1, 1). 2016-044, Warm Springs Natural Area (Clark), 9 Sep 2016. B. Zyla (P, V; Figure 7). First record for Nevada.

Chesser et al. (2014) split the Arctic Warbler into three species, including the Kamchatka Leaf Warbler ( $P$. examinandus) and Japanese Leaf Warbler ( $P$. xanthodryas). These similar-appearing species can be distinguished by song, mitochondrial DNA, and slight morphological differences. The visible characteristics needed to identify a silent bird in the field outside of its breeding range, however, have not been established. Withrow et al. (2016) discussed the occurrence of $P$. examinandus in Alaska, where $P$. borealis nests widely. So far as we know no specimen of this group has been collected in North America south of Alaska, but vagrants have been observed in California (nine September records; https://californiabirds.org//), and there is an October 1991 observation from Baja California Sur, Mexico (Pyle and Howell 1993). 


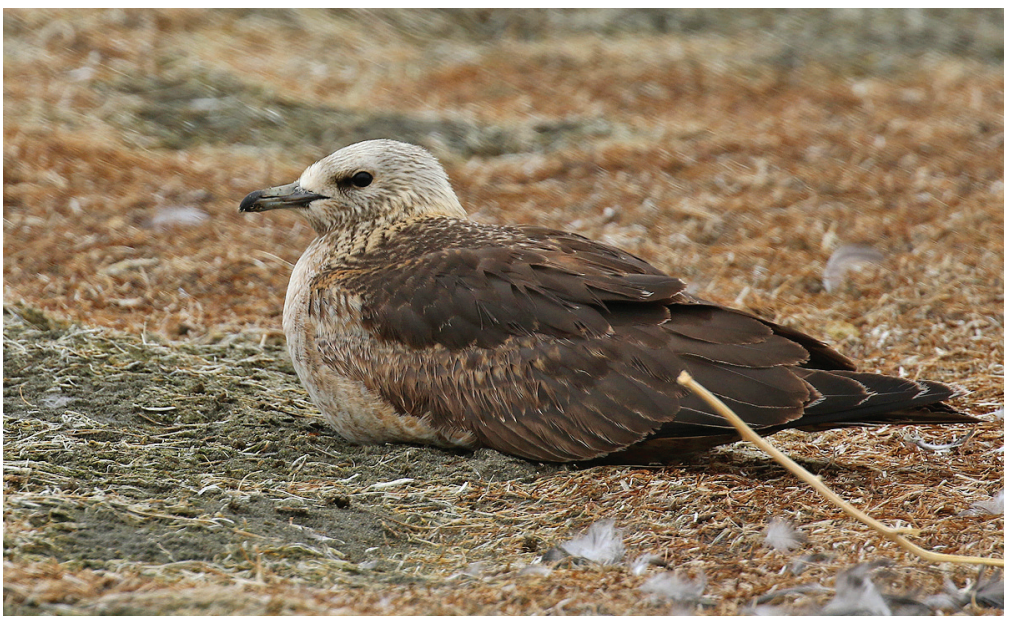

Figure 4. Parasitic Jaeger (Stercorarius parasiticus), 29 Oct-6 Nov 2016, south end of Pyramid Lake, Washoe County, Nevada.

Photo by G. Scyphers

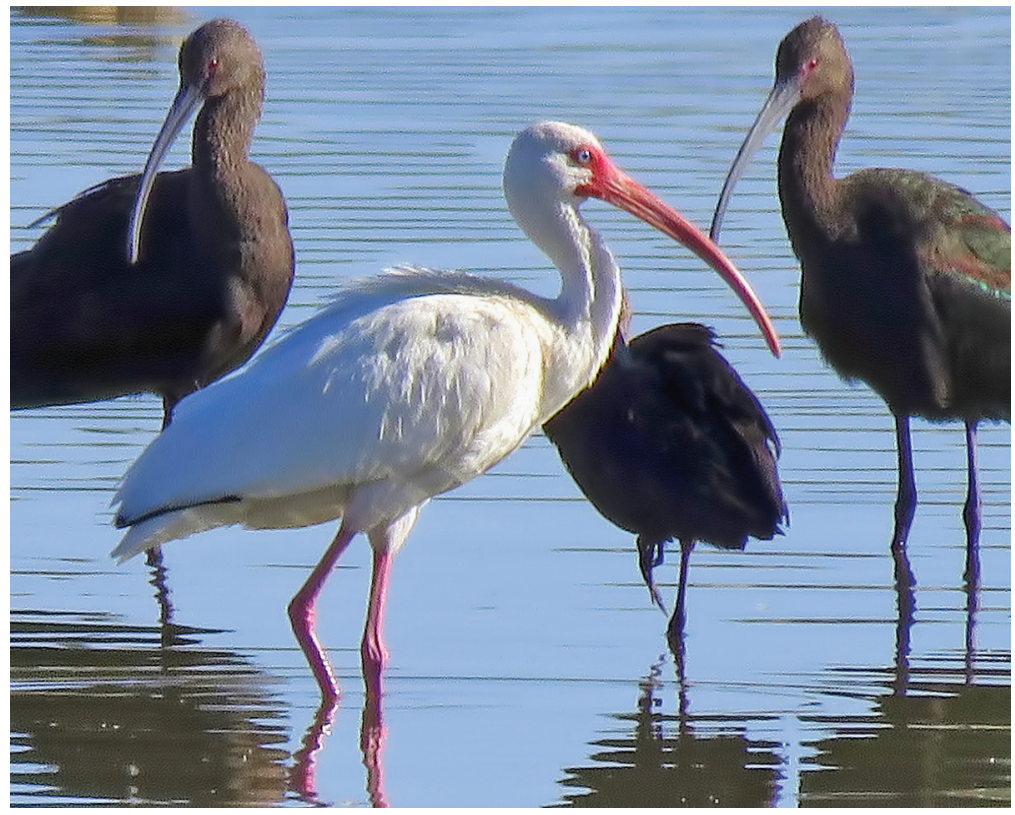

Figure 5. White Ibis (Eudocimus albus), 13-21 Aug 2017, Clark County Wetlands Park and Henderson Bird Viewing Preserve, Clark County, Nevada.

Photo by J. Tinsman 


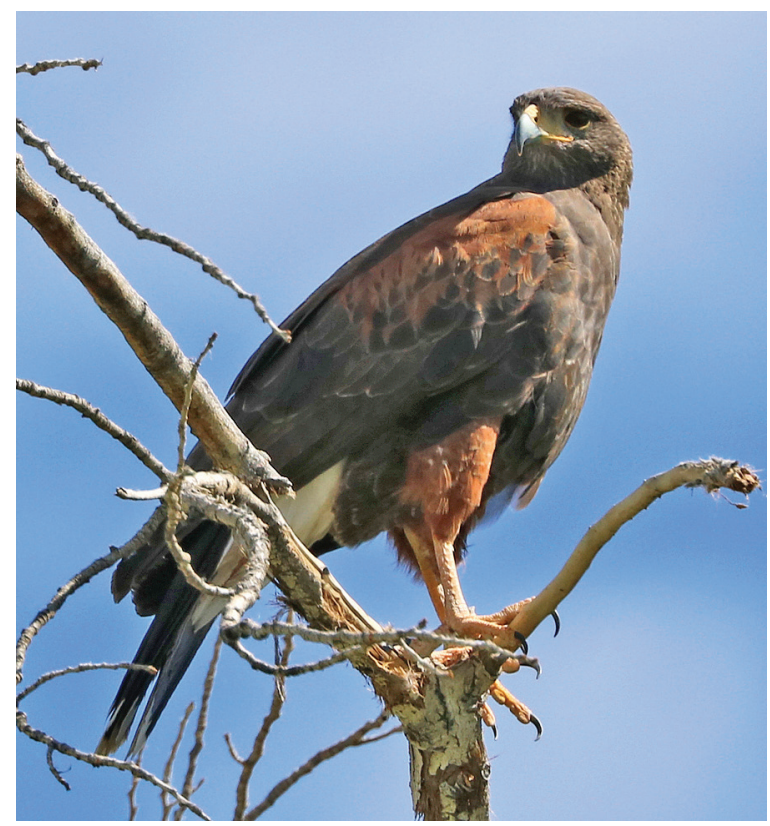

Figure 6. Harris's Hawk (Parabuteo unicinctus), 21 Mar-2 Apr 2017, Floyd Lamb Park, Clark County, Nevada.

Photo by P. Gaffey

The subject of this record was silent during the observation. We will revisit this record if additional information enabling field identification becomes available.

PURPLE FINCH Haemorhous purpureus (10, 1). 2017-006, Verdi (Washoe), 31 Jan-2 Feb 2017, 14 birds. G. Scyphers (P); M. Meyers (P; Figure 8), J. Bleam (P), A. de Queiroz (P), P. Hurtado. Different observers saw varying numbers of Purple Finches at this location, with 14 being the reported high count for the three-day period.

2017-047, Pahranagat NWR (Lincoln), 27 Aug 2017. NOT ENDORSED.

Of Nevada's 10 endorsed records of the Purple Finch, six are scattered between 2003 and 2014; one or two were recorded in a year, but not every year. Observations have taken place in the western part of the state from Washoe County south to Esmeralda County. Since 2014, observations have been increasing in frequency and number of birds per sighting. The three records in 2016 represented 10 birds, and for the first time Purple Finches were documented in southern Nevada (Clark County).

Though the NBRC endorsed only one record in 2017, at least 14 birds were seen over three days. Records slated for review in 2018 include 11 observations of 26 birds, in both western and southern Nevada.

Alcorn (1988:378) rated the Purple Finch as "rare" in Nevada. Though he listed 12 observations from 1958 through 1985, Ryser (1985) suspected that some sightings could have been of misidentified House Finches ( $H$. mexicanus) or Cassin's Finches (H. cassinii). None of these reports have been reviewed by the NBRC.

Although the Purple Finch nests as close as the west slope of the Sierra Nevada in California, it is known to breed on the east slope at only two locations, around 
Susanville (Lassen County) and near Markleeville (Alpine County), both in California (Beedy and Pandolfino 2013).

SNOW BUNTING Plectrophenax nivalis $(3,1)$. 2017-062, Lake Mead Fish Hatchery, Lake Mead NRA (Clark), 1-2 Jan 1984. J. Cressman, M. Cressman; M. Kasprzyk (P), C. S. Lawson (P, Am. Birds 38:341, 1984). Earliest NBRC-endorsed record.

*LARK BUNTING Calamospiza melanocorys (18**, 3). 2017-055, Boulder City (Clark), 6 Feb 1940. Collected by S. G. Jewett (MBM 2799/UWBM 97119, o). Earliest NBRC-endorsed record. Jewett (1940) reported the largest incursion of the Lark Bunting known in Nevada in February 1940, with up to eight at Corn Creek Ranch, about 100 between Las Vegas and Boulder City, and "a hundred or more" at Searchlight.

2017-053, Searchlight (Clark), 3 May 1952. Collected by G. W. Gullion (MBM 2797/UWBM 97118, ơ). Strangely, Gullion et al. (1959) mentioned only the collection of another specimen taken on the same date, currently housed in the Museum of Vertebrate Zoology, University of California, Berkeley. These birds were part of another incursion: from about 2 to 14 May 1952, Gullion et al. (1959) reported flocks around Searchlight, the Las Vegas Valley, Coyote Wells, Pahranagat Valley, Delamar Flats, and Meadow Valley.

2017-054, Overton WMA (Clark), 26 Aug 1996. Collected by D. F. Parmelee (MBM 4257/UWBM 97120, imm. o, moderate fat, no molt, skull not ossified).

GRASSHOPPER SPARROW Ammodramus savannarum (14, 2). 2017-066, Spring Mountain Ranch SP (Clark), 17 Oct 2017. B. Zyla (P).

2017-067, Ash Meadows NWR (Nye), 17 Oct 2017. D. Feener (P; Figure 9).

BALTIMORE ORIOLE Icterus galbula $(13,1)$. 2017-065, Floyd Lamb Park (Clark), 12 Sep 2017. J. Streit (P).

RUSTY BLACKBIRD Euphagus carolinus (6, 1). 2017-059, Henderson tailing ponds (Clark), 21 Mar 1978, two birds. Collected by C. S. Lawson (MBM 3067 [B1697]/UWBM 101943; o, light fat, head and neck in molt; MBM 3068 [B-1696]/ UWBM 101944; 9 , heavy fat, head and neck in molt; Alcorn 1988).

WORM-EATING WARBLER Helmitheros vermivorum (13, 1). 2017-043, Dyer (Esmeralda), 28 May 2017. G. Scyphers (P).

*PROTHONOTARY WARBLER Protonotaria citrea (15**, 1). 2017-025, Little Valley (Washoe), 31 May 1962. Collected by F. A. Ryser (UNMB 1222; ơ, found dead; Ryser 1963). Earliest NBRC-endorsed record.

*TENNESSEE WARBLER Oreothlypis peregrina (19**, 2). 2017-026, Corn Creek, Desert NWR (Clark), 26 May 1965. Collected by C. G. Hansen (MBM 2293 [B-872]/UWBM 98915; o, light fat, skull fully ossified).

2017-027, Corn Creek, Desert NWR (Clark), 26 May 1965. Collected by C. G. Hansen (MBM 2292 [B-873]/UWBM 98914; 0", moderate fat, skull fully ossified).

The two specimens constitute the earliest NBRC-endorsed records, as they were collected on the same date (Austin 1969).

MOURNING WARBLER Geothlypis philadelphia (3, 1). 2017-030, Dyer (Esmeralda), 27-28 Sep 1991. P. E. Lehman; S. Finnegan (P; Am. Birds 46:129, 1992). Earliest NBRC-endorsed record.

*HOODED WARBLER Setophaga citrina (11**, 1). 2017-004, Dyer (Esmeralda), 22-23 May 1987. P. E. Lehman, D. Roberson (P; Am. Birds 41:469, 1987). Earliest NBRC-endorsed record. 


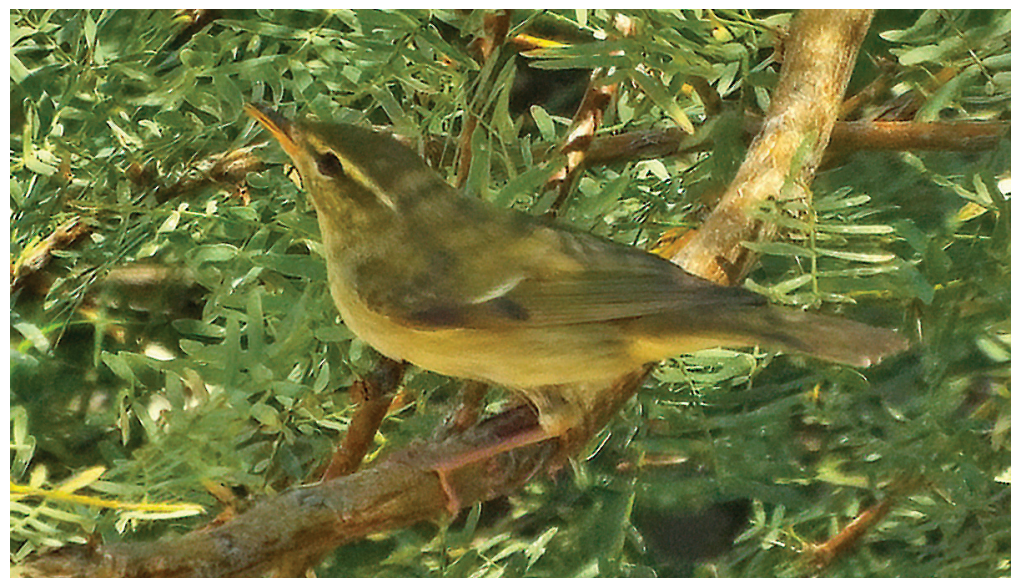

Figure 7. Arctic Warbler (Phylloscopus borealis) sensu lato, 9 Sep 2016, Warm Springs Natural Area, Clark County, Nevada.

Photo by B. Zyla

BAY-BREASTED WARBLER Setophaga castanea (4, 1). 2017-041, Walker Lake (Mineral), 8 Jun 2017. F. Fogarty. Adult male.

BLACKBURNIAN WARBLER Setophaga fusca (9, 2). 2017-061, Floyd Lamb Park (Clark), 2 Oct 2017. P. Gaffey (P).

2017-063, Blue Diamond (Clark), 9-10 Oct 2017. B. Miller (P); C. Moqtaderi, B. Zyla (P).

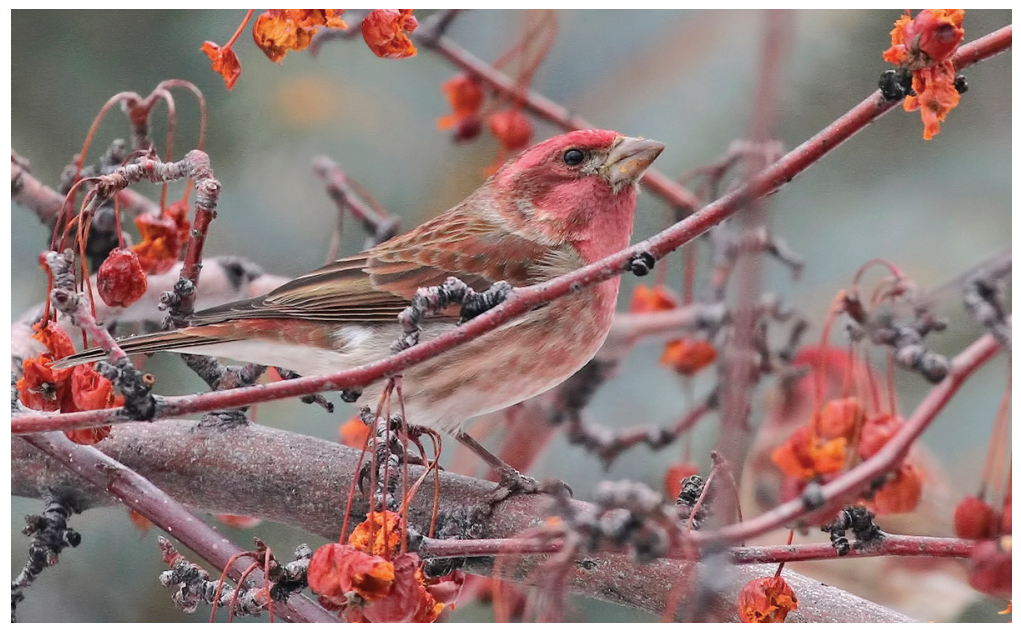

Figure 8. Purple Finch (Haemorhous purpureus), 31 Jan-2 Feb 2017, Verdi, Washoe County, Nevada.

Photo by M. Meyers 


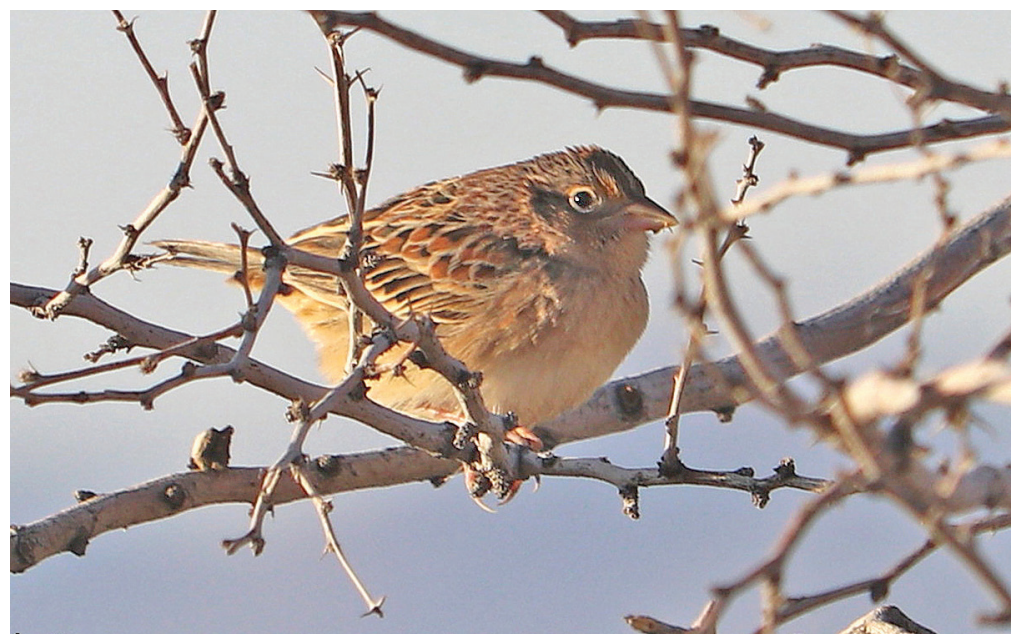

Figure 9. Grasshopper Sparrow (Ammodramus savannarum), 17 Oct 2017, Ash Meadows National Wildlife Refuge, Nye County, Nevada.

Photo by D. Feener

*BLACKPOLL WARBLER Setophaga striata (13**, 1). 2017-028, Corn Creek, Desert NWR (Clark), 2 Oct 1974. Collected by C. S. Lawson (UNMB 1782; imm. , moderate fat, skull unossified; Alcorn 1988). Earliest NBRC-endorsed record.

CANADA WARBLER Cardellina canadensis (8, 3). 2017-022, Hilltop Campground, Spring Mountains (Clark), 19 Jun 1982. M. V. Mowbray (Am Birds 36:1002, 1982). Earliest NBRC-endorsed record.

2017-021, Boulder City (Clark), 3 Oct 1982. M. Kasprzyk (Am. Birds 37:207, 1983).

2017-040, Key Pittman WMA (Lincoln), 31 May 2017. C. Hines (P).

HEPATIC TANAGER Piranga flava (2, 0). 2016-018, Floyd Lamb Park (Clark), 29-30 Dec 1973. NOT ENDORSED.

2016-017, Las Vegas (Clark), 30 May 1994. NOT ENDORSED.

2017-024, Blue Diamond (Clark), 7 Oct 1994. NOT ENDORSED.

The NBRC has reviewed eight reports of the Hepatic Tanager, including these three. Only two have been endorsed (2002 and 2014). Any of these listed here could have represented the earliest observation in Nevada, but documentation was not sufficient for endorsement.

SCARLET TANAGER Piranga olivacea (8, 1). 2017-068, Spring Mountain Ranch SP (Clark), 1 Nov 2017. C. Gaffey (P), P. Gaffey (P).

\section{ACKNOWLEDGMENTS}

The NBRC thanks everyone who contributed to the accounts contained in this report. All submissions, photos, advice, comments, and opinions are greatly appreciated. We apologize to anyone who may have been overlooked. Some of the contributors on this list are no longer with us, but their contributions are no less appreciated: Meg Andrews, B. Arkell, Jeff Aufmann, George T. Austin, Ned A. Batchelder, Art Biale, Jeff Bleam, Dave Boyarski, Carol Cantino, Douglas Chang, Christopher Chappell, G. 
Scott Clemson, Chuck Coxe, James Cressman, Marian Cressman, Dorothy Crowe, Alan de Queiroz, Bruce Deuel, Craig Dodson, Ken Drozd, Darlene Feener, Shawneen Finnegan, Frank Fogarty, Cynthia Gaffey, Patrick Gaffey, Dennis Ghiglieri, Gordon W. Gullion, Charles G. Hansen, Alexander Harper, Lauren Harter, Chance Hines, James F. Holmes, Paul Hurtado, Alvaro Jaramillo, Stanley G. Jewett, Joe Kaplan, Mark Kasprzyk, Christy Klinger, Glade Koch, Kem Kough, Charles S. Lawson, Paul E. Lehman, Wendy McCrady, Neil McDonal, K. P. McGoohan, Martin Meyers, Brandon Miller, Cyrus Moqtaderi, Bob Morrison, M. Vincent Mowbray, David F. Parmelee, Michael A. Patten, Fred Petersen, Don Roberson, Sue Rogers, Gary H. Rosenberg, Nick Rosen, Fred A. Ryser, Nancy Santos, Greg Scyphers, James Shammot, Justin Streit, Rose Strickland, Jane Taylor, Scott B. Terrill, Jane Thompson, Jeanne Tinsman, Carolyn Titus, Jennifer Tobin, Chris Tomlinson, Christina Van Oosten, Fred Welden, Elizabeth Wells, John Yerger, and Ben Zyla.

Outside review was provided by Daniel D. Gibson, Stephen C. Rottenborn, and Philip Unitt. Special thanks to Western Field Ornithologists and Great Basin Bird Observatory for their support and encouragement.

\section{LITERATURE CITED}

Alcorn, J. R. 1988. The Birds of Nevada. Fairview West Publishing, Fallon, NV.

Austin, G. T. 1968a. Additional bird records for southern Nevada. Auk 85:692; doi $10.2307 / 4083386$.

Austin, G. T. 1968b. The occurrence of certain nonpasserine birds in southern $\mathrm{Ne}$ vada. Condor 70:391; doi 10.2307/1365941.

Austin, G. T. 1969. New and additional records of some passerine birds in southern Nevada. Condor 71:75-76; doi 10.2307/1366057.

Beedy, E. C., and Pandolfino, E. R. 2013. Birds of the Sierra Nevada: Their Natural History, Status and Distribution. Univ. Calif. Press, Berkeley.

Chesser, R. T., Banks, R. C., Cicero, C., Dunn, J. L., Kratter, A. W. Lovette, I. J., Navarro-Sigüenza, A. G., Rasmussen, P. C., Remsen, J. V. Jr., Rising, J. D., Stotz, D. F., and Winker, K. 2014. Fifty-fifth Supplement to the American Ornithologists' Union Check-list of North American Birds. Auk 131:CSi-CSxv.

Chesser, R. T., Burns, K. J., Cicero, C., Dunn, J. L., Kratter, A. W., Lovette, I. J., Rasmussen, P. C., Remsen, J. V. Jr., Rising, J. D. Stotz, D. F., and Winker, K. 2017. Fifty-eighth Supplement to the American Ornithological Society's Checklist of North American Birds. Auk 134:751-773; doi 10.1642/AUK-17-72.1.

Gullion, G. W., Pulich, W. M., and Evenden, F. G. 1959. Notes on the occurrence of birds in southern Nevada. Condor 61:278-297; doi 10.2307/1365500.

Jewett, S. G. 1940. The Lark Bunting in southern Nevada. Condor 42:307.

Meyers, M. 2016. Nevada Bird Records Committee report for 2016. W. Birds 47:120-137; doi 10.21199/WB47.2.2.

Pyle, P., and Howell, S. N. G. 1993. An Arctic Warbler in Baja California, Mexico. W. Birds 24:53-56.

Ryser, F. A. 1963. Prothonotary Warbler and Yellow-shafted Flicker in Nevada. Condor 65:334.

Ryser, F. A. Jr. 1985. Birds of the Great Basin: A Natural History. Univ. Nev. Press, Reno.

Tinsman, J., and Meyers, M. 2016. Nevada Bird Records Committee report for 2015. W. Birds 47:274-290; doi 10.21199/WB47.4.2.

Titus, C. K. 1996. Field list of the birds of Nevada. Red Rock Audubon Soc., Las Vegas.

Withrow, J. J., Gibson, D. D., Gerasimov, Y., Gerasimov, N., Shestopalov, A., and Winker, K. 2016. Occurrence and taxonomy of Arctic Warblers (Phylloscopus borealis) sensu lato in North America. Wilson J. Ornithol. 128:268-277; doi 10.1676/wils-128-02-268-277.1. 